\title{
Leveraging Dynamic Export Capabilities for Competitive Advantage and Performance Consequences: Evidence from China
}

\begin{abstract}
As the business arena becomes more global and therefore dynamic, organizations must balance their capabilities with the demands and the conditions of the international marketplace. This leads firms to trade off the development of more capabilities with the identification of core capabilities which can best improve export competitiveness and performance. Based on the Dynamic Capabilities Approach (DCA), we develop a model of four capabilities, namely adaptability, innovativeness, unpredictability, and task-flexibility, aimed at achieving competitive advantage in foreign markets and enhance export performance. Based on a survey of 213 Chinese exporting organizations, we show that capabilities interact differently with firms' competitive advantage under different levels of competitive intensity. We also confirm the necessity of addressing competitive advantage separately from firms' performance.
\end{abstract}

Keywords: Competitive advantage; Adaptability, Innovativeness; Unpredictability, Task flexibility; Performance 


\section{Introduction}

The current international business environment is dynamic and unpredictable, and organizations that operate on the international scene hav to strive to remain competitive and succeed.

Consequently, research into what drives competitive advantage and performance in foreign markets is drawing increasing attention (Augier and Teece, 2007). Dynamic capabilities are particularly relevant in international business (Teece, 2013) where firms are exposed to the effects of globalized competition and the success of international firms is dependent on discovering opportunities, increasing innovation, and finding new ways to compete in international markets.

Dynamic capabilities determine the firm's ability to integrate, build, and reconfigure internal and external resources and functional competencies to address dynamic and everchanging business environments (Teece, 2007, 2012; Teece et al., 1997). To this end, dynamic capabilities are dividable into the capacity to (1) sense and shape export opportunities and threats; (2) seize export opportunities; and, (3) reconfigure the resource-base (tangible and intangible) of international firms to enhance competitiveness (Teece, 2007, 2013). We focus on four specific dynamic capabilities that reflect capacities to sense, seize, and reconfigure: adaptability, innovation, unpredictability, and flexibility. These dynamic capabilities reflect specific organizational and strategic process through which managers alter their firm's resource base (Eisenhardt and Martin, 2000) in seeking advantages and performance outcomes.

The DCA deviates from the Resource-Based View by acknowledging environmental dynamism (Eisenhardt and Martin, 2000) as a central factor when it comes to planning a strategy. According to the DCA, the capabilities' patterns adjust to market dynamics, so while under more stable market conditions they are more robust and process-oriented, under more dynamic conditions they become more flexible and less predetermined (Eisenhardt and Martin, 2000). Similar to the Resource-Based View, DCA also addresses the potential impact of these capabilities on firms' sustainable competitive advantage (SCA) and performance. Since SCA refers to the outcome of an organization developing attributes or capabilities that allow it to outperform its competitors in a way that makes it difficult or impossible for competitors to imitate (Sun and Tse, 2009), dynamic capabilities are viewed as fundamental source of sustained advantages (Reuter, Foerstl, Hartmann, and Blome, 2010). 
Yet, while much attention has been given to firms' capabilities within DCA research, very few attempts have been made to capture the full picture through the integration of both firms' SCA and performance in the same study. Extant research mainly focuses on the capabilities — performance linkage (Sirmon, Hitt, Arregle, and Campbell, 2010) yet advantage is an inherent aspect to the importance of dynamic capabilities (e.g., Teece, 2013) and research is needed to address environmental influences on the relationship between these capabilities and firms' SCA (Luo, 2000). It is even more essential to examine this relationship in the context of Chinese exporters as (a) prior research is lacking in this international context and (b) we avoid the confounding effects from operationalizing advantage and performance in very similar ways. Indeed Asian companies have found it difficult to transfer domestic competitive advantages into international markets. For example, Marukawa (2009) found that Japanese MNEs holding domestic competitive and technological advantages could not translate that into advantage when entering international markets, such as in China. As such, we feel it is necessary and valuable to examine further the advantage-performance relationship in this study.

The findings of this study contribute to international business research in a number of ways. First, we expand on dynamic capabilities research in an attempt to address the call for a greater understanding of the sets of capabilities that underpin competitive advantage, followed by a more focused endeavour addressing the potential effect these capabilities bear on firms' performance (Prange and Verdier, 2011). By looking at this issue from the international angle, we harness the rapid changes embedded in it, therefore gaining most value from the use of the DCA (Tseng and Lee, 2010; Villar, Alegre, and Pla-Barber, 2014). The dynamic capabilities examined here reflect key elements of sensing, seizing, and reconfiguring. We do not proclaim to focus on all relevant dynamic capabilities as there are many others that could be considered. However, these have been identified as pertinent for international businesses to harness in competitive environments (Teece, 2013) and are as yet untested as a set in international business research. Second, we address the competitive advantage-performance relationship by following Ambrosini and colleagues' (2009) statement that a clearer understanding of what impacts firms' competitive advantage is necessary. Therefore, we advance understanding on specific dynamic capabilities and how these generate advantage and advance the work of Newbert (2008) in divorcing competitive advantage from performance as current understanding of competitive 
advantage is being confounded by researchers operationalizing advantage in performance terms (e.g., profitability).

From a managerial perspective, the results of the study can help managers prioritize and allocate resources appropriately to the development of different capabilities. It is especially relevant for Chinese exporters, which, on average have been involved in international trade for a shorter period in comparison to their Western counterparts (Mathews, 2002). Furthermore, firms from emerging markets often struggle to fit their strategy with their environment to gain advantage (Bhaumik, Driffield, and Zhou, 2016). Thus, Chinese companies require more detailed knowledge on how to further develop their internal strengths to be able to outplay competitors in the international market (Deng, 2009).

In the next section, we discuss the four dynamic capabilities, sustainable competitive advantage and performance, and follow this with the development of a set of hypotheses establishing the relationships between them. We outline our methodology and proceed to test the hypotheses using an AMOS-based path analysis. We conclude by discussing findings, contribution, and further research avenues.

\section{Conceptual Framework}

Barney, Wright and Ketchen (2001), argue for a better understanding of the capabilities sustaining competitive advantage. They claim that based on previous research, firms cannot achieve SCA under a turbulent environment unless they utilize their capabilities in accordance with these conditions. Capabilities are defined as the "ability of an organization to perform a coordinated set of tasks, utilizing organizational resources, for the purpose of achieving a particular end result" (Helfat and Peteraf, 2003 p. 999). Barney, Wright and Ketchen (2001 p. 631) argue that "...firms in a rapidly changing market are more nimble, more able to change quickly, and more alert to changes in their competitive environment, they will be able to adapt to changing market conditions more rapidly than competitors, and thus can gain competitive advantage". We contend that dynamic capabilities can explain such a conclusion. Thus, being quicker, more flexible and adaptive are three aspects of a firm's capabilities that need to be maintained in order to facilitate SCA (Eisenhardt and Martin, 2000). As such, capabilities that entail an ability to adapt, or change relatively quickly, play a central role in forming competitive advantage (Lin and Wu, 2014). Drawing on this line of thought, capabilities cannot be viewed as 
equivalent and interchangeable, though clusters of capabilities might share similar (dynamic) characteristics which, together, may drive superior international business performance (Prange and Verdier, 2011).

International capabilities are developed through learning and the creation of unique international know-how (Villar, Alegre, and Pla-Barber, 2014; Yalcinkaya and Griffith, 2007). Both the learning process and the unique know-how created through it serve to form the principles of dynamic capabilities as quick, flexible and adaptive, which are embodied within the endeavour to adjust to the firm's environment while aiming to achieve better results (López, 2005). In a sense, they represent the firm's shock absorbers, enabling the firm's competitive advantage to adjust with every shift and change in the international trade environment, hence its sustainability (Wu and Voss, 2015). Previous research addresses the centrality of capabilities in facilitating SCA in the international market place (Fahy, 2002; Griffith and Harvey, 2001).

Eisenhardt and Martin (2000) recognize cross-functional working as a key microfoundation of dynamic capabilities and Felin, Foss, Heimeriks, and Madsen (2012) indicate that process for cross-functional working and decentralized structures can facilitate resource reconfiguration.

Taken together, export adaptability, export innovation, export unpredictability, and export taskflexibility are dynamic capabilities that international firms can rely on and reflect a firm's capability to sense, seize and reconfigure and meet Teece's (2014) categorization of dynamic capabilities.

Consequently, we address this issue by examining dynamic export capabilities in a study that also links these to sustainable international competitive advantage and export performance, and considers the moderating effect of competitive intensity in the foreign trade environment (Zou, Chen Ghauri, 2010).

An export organization's ability to adapt to its foreign environment is key to its export performance (Morgan, Zou, Vorhies, and Katsikeas, 2003). Adaptability enables firms to seize opportunities and reconfigure their resource-base to adapt quickly to competitor actions and external threats. Adaptability is sometimes also referred to as responsiveness, defined as the ability to adapt to external changes (Bhatt et. al. 2010). Responsiveness is in turn mainly studied as a behavioural component of export market orientation (Cadogan, Cui, and Kwok Yeung Li, 2003). While most studies examined the indirect effect of export responsiveness on competitive advantage, either by exploring some capabilities as mediators (Murray, Gao, and Kotabe, 2011), 
or as an antecedent to the formation of competitive capabilities in an export context (Kaleka, 2002), few have referred to the main principle of responsiveness, being the willingness to adapt to external changes.

At the same time firms that are able to respond promptly to opportunities and threats are known to be more successful than their competitors (Dibrell, Down and Bell, 2007). The macroenvironment -- that includes new market opportunities, competitor threats and changing customer needs -- can be argued to be beyond the control of managers, who therefore need to be able to adapt to it quickly to ensure long-term competitive superiority (Lyus, Rogers and Simms, 2011; Nemkova et al., 2015). The ability to respond quickly to environmental changes can help to outperform competitors and achieve competitive advantage as more responsive companies can better capitalise on fast-moving market opportunities (Jayachandran, Hewett and Kaufman, 2004; Sousa, Ruzo and Losada, 2010).We therefore predict the following:

Hypothesis 1a Export adaptability is positively related to sustainable competitive advantage.

While export adaptability is notionally and intuitively a key capability for many organizations, its positive outcomes are, in actual fact, not guaranteed. For example, Griffith, Lee, Seob Leo and Calantone (2014) find contingents in the process adaptation - export performance relationship. The export market orientation literature also finds strong support for competitive intensity moderating the export responsiveness-export performance relationship (Cui, Griffith, and Cavusgil, 2005). Some advocate for the growing necessity of adaptability under higher competitive intensity, drawing on similar findings regarding knowledge-based capabilities (Auh and Menguc, 2005) and marketing capabilities (Cadogan, Diamantopoulos, and Siguaw, 2002; Doyle and Wong, 1998). Others claim that in order to preserve certain levels of adaptability in the export market, firms must invest substantial resources and often this investment does not produce a sufficient return due to the dynamics associated with the export markets (Rose and Shoham, 2002). Following this line of thought, we propose the following.

Hypothesis 1b The relationship between export adaptability and competitive advantage is stronger when competitive intensity is lower. 
Export innovativeness reflects the capacity of the export firm to use new methods, techniques, and ideas in export processes and goes beyond simply being proficient at R\&D. Indeed, Teece (2013) indicates that the latter is not sufficient for success unless innovation extends into reinventing the processes of the firm, consistent with the definition of dynamic capabilities. Innovation and innovativeness are often used interchangeably, yet represent two different constructs (Garcia, 2002). Innovation is related to 'the successful implementation of creative ideas' (Amabile, Conti, Coon, Lazenby, and Herron, 1996 p. 1). Innovativeness is regarded as the capacity to introduce new processes, products, or ideas in the organization (Hult, Hurley, and Knight, 2004), hence it relates to the firms' willingness to engage in innovation. The present study investigates innovativeness capability as the facilitation of "newness" in organizational processes (Hult, Hurley, and Knight, 2004; Wang and Ahmed, 2004). In an export context, this refers to engaging new processes and mechanisms when dealing with export markets. Hult, Hurley and Knight (2004) claim that innovativeness drives competitive advantage by enabling firms to cope better with the evolving environment. This relationship was tested in the information technologies field, while using the DCA framework. Process innovativeness interpreted through reconfiguring and leveraging competencies, showed a significant impact on competitive advantage (Pavlou and Sawy, 2004). In an export context, innovativeness is likely to be further necessitated due to the dynamic nature of the environment as a whole. Those exporters able to display new ways of thinking and operating are more likely to derive competitive advantages. In the words of Boso et al (2013, p.62), "from a resource-based perspective, innovativeness is valuable and idiosyncratic to firms, an intangible asset that may provide businesses with competitive advantage by virtue of being too costly for rival firms to replicate". We therefore expect the following.

Hypothesis 2a Export innovativeness is positively related to sustainable competitive advantage.

That said, the benefits of export innovativeness are also contingent rather than universal (Boso et al., 2013). As for the moderating relationship of competitive intensity, while some research states that such a relationship bears a positive influence on firms' performance, this finding is somewhat inconclusive, a fact which may be due to the overlap of innovation and innovativeness (Damanpour, 1991; Han, Kim, and Srivastava, 1998; Menguc and Auh, 2006). Santos-Vijande 
and Alvarez-Gonzalez (2007) find that while under stable environments, innovativeness will positively impact the firms' innovation capacity, under turbulent environment this impact diminishes. When the environment is stable, innovativeness challenges the traditional way of doing things and encourages deviation from the status quo (Sethi, Smith, and Park, 2001). This, in turn, enables the firm to differentiate itself from competitors and stand out in the market (McNally, Cavusgil, and Calantone, 2010). Conversely, under conditions of unstable environment, the introduction of innovations to the market becomes more risky and often less rewarding (Calantone, Garcia, and Droge, 2003). Being associated with a trial-and-error process, innovativeness has a high potential to lead to a mistake when customer preferences are rapidly changing (Moorman and Miner, 1998). As market trends are less predictable in foreign markets, innovations that are less relevant will fail to outperform competitors in export markets. Thus we propose that:

Hypothesis $\mathbf{2 b}$ The relationship between export innovativeness and competitive advantage is stronger when competitive intensity is lower.

Van den Bosch et al. (1999) claim that a turbulent environment will facilitate a rapid development of capabilities, due to the ever increasing necessity to cope with the dynamic environment while preserving a competitive edge. Following this, our third capability, unpredictability, is associated with turbulent environment. Export unpredictability revolves around surprise, creating the unexpected, and undertaking hard to foresee actions in international markets (Austin, Devin, and Sullivan, 2012) that enable international firms to shape new rules of engagement in competitive environments. Teece (2013) identifies such a dynamic capability as a key success ingredient in international business. While we address it at the firm level, the issue of unpredictability was associated previously with the environment; in other words, unpredictability is usually treated as an uncontrollable characteristic of the environment. By contrast, the organization's unpredictability can be developed as a deliberate strategy, and therefore become a valuable capability (Austin, Devin, and Sullivan, 2012). In turn, if the decisions made by organizations were not anticipated by the competition, they are more likely to lead to competitive advantages (c.f. Miles, Snow, Meyer, and Coleman Jr, 1978). In support of this claim, Griffith and Harvey refer to international predictability as "...the ability to foretell 
exchange circumstances ex ante" (2001, p.600). As such, it leads to a strategic certainty which allows for a better forecasting and planning. Therefore, if predictability is needed for better planning and hence performance, when firms are being unpredictable, they are pulling the rug from underneath their competitors. Based on this, we argue that firms that perform export unpredictably become more intimidating, therefore gaining an advantage in the foreign market place. Thus, such firms are relying on a capability to be unpredictable as part of their competitive advantage (Homburg, Workman Jr., and Krohmer, 1999).

Hypothesis 3a Export unpredictability is positively related to sustainable competitive advantage.

In order for a firm to be unpredictable in its export markets, it needs to be consider as such in comparison with its export competitors (Austin, Devin, and Sullivan, 2012). Thus, export unpredictability capability is measured against the industry's stability, the more stable the industry's competitive intensity, the more effective this capability becomes. That is, unpredictability will provide better value when the industry within which the firm engaged in unpredictable moves, is less dynamic. Therefore, high levels of competitive intensity compromise the benefits of acting unpredictably. Hence:

Hypothesis 3b The relationship between export unpredictability and competitive advantage is stronger when competitive intensity is lower.

The fourth capability is export task-flexibility. It is defined as the extent to which organizational members will substitute for one another (Campion, Medsker, and Higgs, 1993). In an export context, it reflects cross-functional working and responsibilities by employees, such that export staff can inter-change and work cross-functionally on sales, marketing, service, customer support and so forth. This capability serves in maintaining stable, and productive working relationships due to bottom-up coordination between team members (Van Der Vegt, Geben S., Bunderson, and Kuipers, 2010).

Task flexibility has an impact on different aspects of firms' effectiveness since it allows firms to overcome specific peaks, and to maintain a flow of internal processes (Van Der Vegt, Geben S., Bunderson, and Kuipers, 2010). Similarly, Jacobs and Washington (2003) claim that it 
is often viewed as embedded within employee development, and as such it exerts an impact on various organizational outcomes. The subject of task flexibility has received some attention ( $\mathrm{Li}$ and $\mathrm{Li}, 2000$ ), in regard with SCA. Drawing on previous research, we can speculate that such a capability will improve the firm's ability to cope with changes in its environment, thus enhance SCA (Verdú-Jover, Gomez-Gras, and Lloréns-Montes, 2008). Additional evidence can be found in Byrd and Turner (2001) who found that IT personnel flexibility improves competitive advantage.

Hypothesis 4a Export task-flexibility is positively related to sustainable competitive advantage.

Volberda (1996) claims that flexibility must incorporate a certain level of stability for it to serve as a productive capability. In turbulent environments often characterizing foreign trade, flexibility can result in chaos - increasing costs, and harming the firms' decision-making. Similarly, Sanchez (2004) addresses flexibility of different organizational levels claiming that while operating (task) flexibility has a positive impact under stable conditions, when the environment becomes dynamic, operating flexibility cannot serve as a standalone process but needs to be accompanied by different aspects of resources and managerial flexibilities in order to provide the same positive impact. Hence, high levels of task flexibility, in stable environments, enable firms to use their employees more efficiently (Campion, Medsker, and Higgs, 1993; Gibson and Birkinshaw, 2004; $\mathrm{Li}$ and Li, 2000), but in unstable conditions the capability increases the cost of organizational management due to the constraints it imposes on the divisions' managers. Therefore:

Hypothesis $\mathbf{4 b}$ The relationship between export task flexibility and competitive advantage in export markets is stronger when competitive intensity is lower.

Competitive advantage and firm performance are often used interchangeably (Newbert, 2008). Viewed as a means to an end, competitive advantage is often regarded as facilitated by superior value creation (Adner and Zemsky, 2006), therefore leading to enhanced performance (Grahovac and Miller, 2009). Yet, whether defined by a set of capabilities enabling firms to achieve better performance (López, 2005) or viewed as performance-contingent (Peteraf and Barney, 2003) 
competitive advantage is still poorly understood not least due to confounding effects from operationalizing competitive advantage in performance terms. Following the logic of Cockburn, Henderson, and Stern (2000), competitive advantage could result from an initial set of conditions (e.g., differentiation, innovation, clearer market positioning, superior product value etc) that aided in delivering superior profitability in an export market. This can be eroded over time as competitors with poorer initial conditions implement strategic responses to catch-up fast—or level the playing field — to bring about convergence and so more level profits, or as new competitors enter the sphere with innovative products and so forth. In this case surely the basis for initial competitive advantage is what was eroded as competitors make strategic adjustments to raise their own profitability.

Ambrosini and colleagues (2009) emphasize the importance in fully understanding the nature and source of each capability leading to competitive advantage. They claim that in case of a misunderstanding, the competitive advantage might be jeopardized and although in terms of performance indicators such a misunderstanding might not immediately be noticed, it will eventually lead to a negative impact in the long run. An examination of the literature regarding competitive advantage reveals that though the subject has received substantial attention, in most empirical studies it is not measured directly. Instead, performance indicators such as profit are used as proxies. Powell (2001) addresses the differences between a firm's performance, and competitive advantage, saying that the former is contingent on the latter. We follow Powell's (2001) statements and separate between competitive advantage, and performance. This separation can also facilitate a better understanding of how competitive advantage and performance interplay, and how this interaction enhances performance (Chadee and Kumar, 2001).

Kaleka (2011) asserts that the relationship between competitive advantages and performance in the export context has been insufficiently researched and much research in the marketing and strategy literatures tend toward speculation. Research into competitive advantage in exporting have found various positive [strategic, venture, product] performance effects (Kaleka, 2011; Leonidou, Palihawadana, and Theodosiou, 2011); competitive advantage as mediation mechanisms for translating export performance gains from market orientation and specific marketing capabilities (ordinary capabilities distinct from dynamic capabilities)

(Murray, Gao, and Kotabe, 2011); and also some non-significant relationships, such as with 
export financial performance from export product competitive advantages (Leonidou, Palihawadana, and Theodosiou, 2011). Indeed the relationship between advantage and performance is not so clear in exporting. Studies have found for instance that domestic competitive advantage does not necessarily translate into export markets (e.g., Marukawa, 2009).

We depart from much of the literature on competitive advantage in exporting and conceptualize export performance in terms of customer-based dimensions of retention, satisfaction, and growth rather than in financial terms. Accordingly, it is suspected that developing competitive advantages will create positions for exporters to better satisfy customers relative to rivals. Indeed the dynamic capabilities examined here enable firms to sense and seize on export opportunities and reconfigure/transform resources to address export market needs.

Thus, we suspect that export performance will rise as a result of developing competitive advantages:

Hypothesis 5 Competitive advantage in export markets is positively related to export performance.

\section{$\underline{\text { Figure } 1 \text { - Research model }}$}

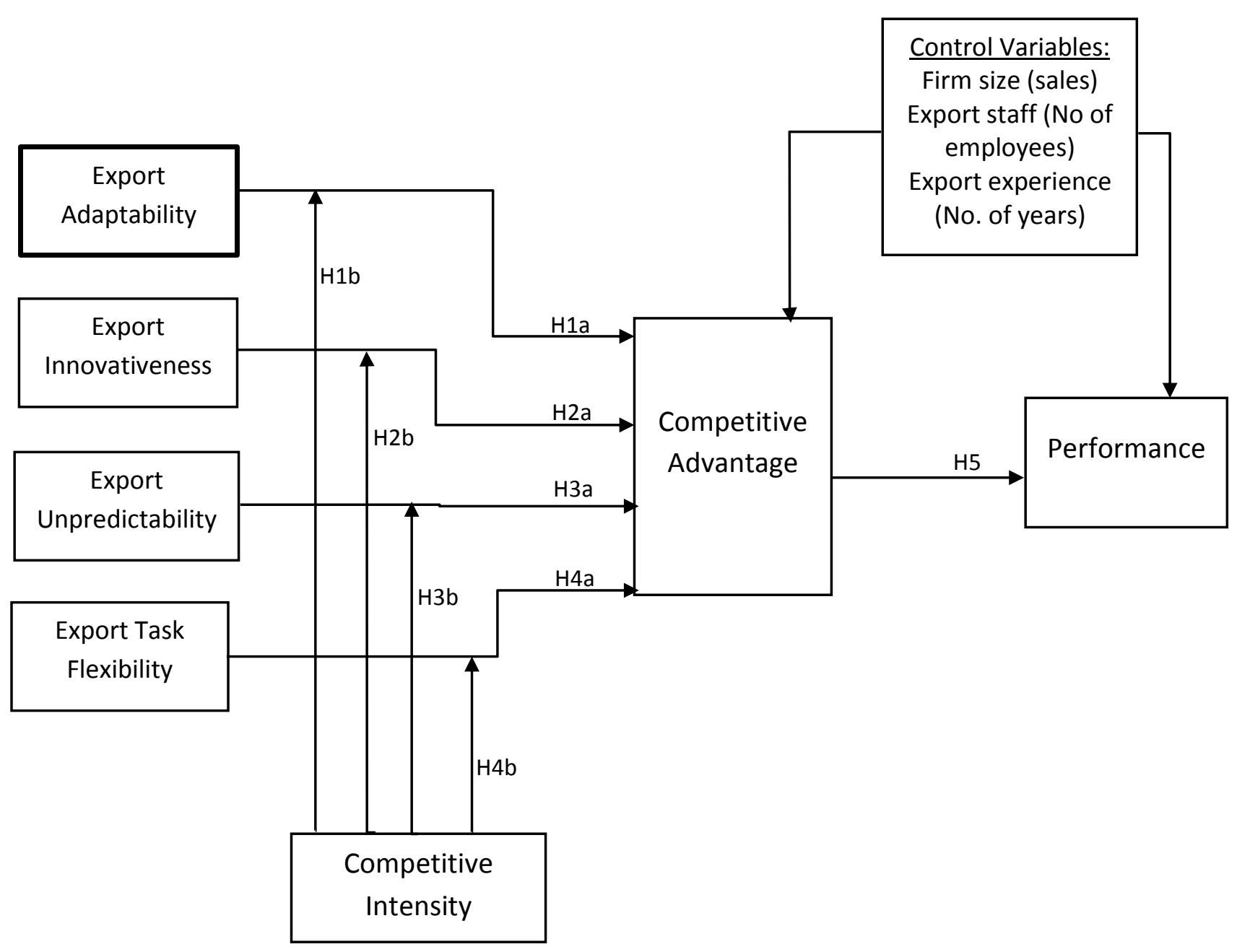




\section{Methodology}

First, the study was conducted within the context of exporting organizations. The current business environment shows evidence of continued globalization and intense competition, which contribute to accelerated internationalization of firms (Morgan, Katsikeas, Vorhies 2012). It is therefore topical to increase our understanding of firm behavior and performance drivers in international markets (Zou, Fang, Zhao 2003). In turn, "any comprehensive answer to the increasingly important question of what drives firms' international competitiveness has to encompass the factors that affect firms' ability to compete in export markets" (Morgan, Katsikeas, Vorhies 2012: 271). In this context, exporting is by far the most common form of internationalization, and the study of export performance one of the most researched topics within this area (Leonidou, Katsikeas 2010). This is even more so when it comes to firms from emerging markets who often struggle to adapt to the demanding conditions associated with the international arena (Wu and Voss, 2015).

There is existing evidence that capabilities are important to export performance (Griffith, Dimitrova 2014, Lee et al. 2009). A large body of recent research refers to either the capabilitiesexport performance linkage (Kaleka, 2012; Lisboa, Skarmeas, and Lages, 2011; Lu, Zhou, Bruton, and Li, 2010; Morgan, Vorhies, and Mason, 2009), or the export capabilities-competitive advantage linkage (Murray, Gao, and Kotabe, 2011; Weerawardena and Mavondo, 2011). However, this body of work still largely ignores the central role the SCA plays in achieving enhanced performance. SCA acts as an integrator of export capabilities, through which these capabilities are transformed into a significant value offering (Murray, Gao, and Kotabe, 2011). By ignoring SCA as a potential mediator in the capabilities-export performance relationship, these studies distort our understanding of what drives firms' export performance (Piercy, Kaleka, and Katsikeas, 1999).

Second, China was chosen as the context for the study. Much DCA research is conducted in Western contexts. However, DCA principles may not be automatically transferred to emerging economies (Guillen, 2000) or China (Chan, 2005; Verbeke and Yuan, 2013). Thus, more work is required in these contexts to ascertain generalizability. In addition, most studies on the drivers of export performance tend to be conducted in developed countries. China, however, is the largest emerging economy and "it is essential for firms competing in the global market to understand the export behavior of Chinese firms" (Zou, Fang, Zhao 2003: 32). 
A large-scale survey of Chinese export manufacturers was conducted to test the hypotheses presented above. The sample frame was formed based on a recommendation list provided by Ningbo Customs official, Weibo's LinkedIn application, Baidu Tieba listings and from the FOB Business forum in China, which is the biggest foreign trade sector website in the country with 2,203,774 members. Ningbo has one of China's busiest port facilities. Baidu Tieba is the Chinese counterpart of Google groups. Two ways of reaching the target respondents were used: offline and online. Offline respondents were chosen from the list provided by the Ningbo Customs and Weibo LinkedIn, while online respondents were taken from Baidu Tieba and FOB Business Forum. Respondents were offered a copy of the findings as incentive to take part in the survey. Responding companies came from all over China, with $80 \%$ of them from Shanghai and Zhejiang province, two of China's most developed industrial regions.

Sampled companies cut across all corporate sizes in China from small (less than 50 employees) to large companies (over a 1000 employees). The majority of them (over 50\%) export to over 10 countries in the world, though in line with the findings of previous research $90 \%$ of the companies have been exporting for less than 10 years and do not have a lot of export experience (e.g. Mathews, 2002).

Key informants were the principal export decision-makers within each firm. The suitability of each potential respondent was verified by two researchers prior the data collection. The exact job title was not specified in advance as different types of managers (e.g., export manager, marketing and sales director, managing director, etc.) are in charge of export duties depending on the structure and size of the firm. The use of a single informant was considered to be appropriate for the current study for a number of reasons. First, the use of a single informant is acceptable if the respondent is knowledgeable about the subject. The knowledgeability of each respondent was therefore verified using a bank of items. Second, it is often the case that one person in the export department is the key decision-maker for export matters. As a result, 'generating information from multiple informants on export marketing issues may lead to the generation of data from individuals who are not very knowledgeable about the firm's export operations, and thereby decrease the accuracy of the information provided' (Sousa, MartínezLópez, and Coelho, 2008 p. 349). Third, it is not unusual for the export department to consist of only one person, or for a manager to combine his/her other responsibilities in a company 
(especially in SMEs) with export duties. In this context, the use of multiple respondents can create a bias.

The Dillman (2007) method was applied to gather responses by mail (phone prenotification, and four waves of follow-ups were conducted). As a result, 213 usable questionnaires, and 47 non-usable ones (questionnaires uncompleted) were received (of the total 270 questionnaires were received, 111 were from the offline method and 159 from the online method. A response rate of $79 \%$ was therefore achieved. The main reasons for non-response were identified including information confidentiality, and lack of time to complete the questionnaire. Nonresponse bias was tested by comparing early, and late respondents (Armstrong and Overton, 1977). No significant differences were found on sample characteristics.

Most of the measures were sourced from existing scales in marketing literature or where scales didn't exist (for unpredictability and task flexibility), terminology employed in conceptual definitions was used to develop pools of items. All measures were adapted for exporting. . To measure innovativeness we used items from Kaleka (2011). Adaptability items were based on the measures proposed by Cadogan, Cui and Li (2003) which reflect the ability to adjust to environmental conditions in a timely fashion. Competitive intensity was captured with four items based on Kaleka and Berthon (2006). Competitive advantage was measured with four items taken from Morgan, Kaleka and Katsikeas (2004) and Kaleka (2002); items were related to cost, service and product competitive advantage. The items for export performance were adapted from Hultman, Robson and Katsikeas (2009). These can be found in the Appendix. All items were 7point Likert-type scales. We also included three control variables: firm size, number of export staff members, and export experience measured by the number of years in export. Analytical procedures included using exploratory factor analysis (principal axis factoring) followed by confirmatory factor analysis using AMOS to assess the psychometric properties of the scales used. This was followed by structural equation modelling also in AMOS. To test the moderating effect of competitive turbulence, interaction terms were created by multiplying turbulence with each of the capabilities in turn, and residual-centring the resulting variable in a bid to avoid multi-collinearity (see Appendix 1 for detailed items).

Prior to administering the survey we followed protocols by Spector and Brannick's (1995) for limiting common method variance (CMV). Attention was given prior to data analysis to potential CMV problems (Podsakoff, MacKenzie, Lee, and Podsakoff, 2003). First, we used 
the Harman single-factor test, and found no common factor arising from the data. Second, we examined CMV through the marker variable technique (Lindell and Whitney, 2001; Malhotra, Kim, and Patil, 2006), using social desirability as a [theoretically unrelated] marker variable. Using this marker variable, we computed a CMV-adjusted covariance matrix between all the main study variables. In comparing the original CFA results to the CMV-adjusted CFA, we found no significant changes in factor loadings between the two CFAs, or any significant difference in model fit. While we cannot entirely rule out CMV effects, the analysis suggests this bias is not likely to explain relationships between the study constructs. Additionally, we conducted a second wave data collection targeted at the performance variables. We managed to collect data from 81 firms included in the original data collection. A correlation analysis of the same performance variables between the original data and the second wave data, revealed a high correlation $(.670, \mathrm{p}<.001)$, confirming consistency.

\section{Results}


Table 1 reports the descriptive statistics, average variance extracted (AVE), composite reliability (CR), correlations, and square-rooted AVEs for each of the constructs. The

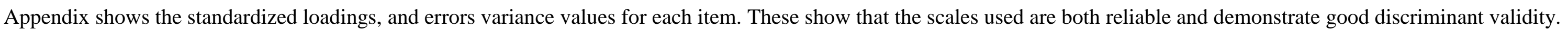

Table 1 Descriptive Statistics and Correlation Matrix

\begin{tabular}{|c|c|c|c|c|c|c|c|c|c|c|c|}
\hline & $\mathrm{CR}$ & AVE & Mean & $\mathrm{Sd}$ & 1 & 2 & 3 & 4 & 5 & 6 & 7 \\
\hline 1. Export adaptability & 0.88 & 0.63 & 4.75 & 0.96 & 0.85 & & & & & & \\
\hline 2. Export task flexibility & 0.84 & 0.64 & 4.60 & 1.24 & $0.21 * *$ & 0.80 & & & & & \\
\hline 3 Export innovativeness & 0.84 & 0.63 & 4.70 & 1.03 & $0.46 * *$ & $0.29 * *$ & 0.79 & & & & \\
\hline 4. Export unpredictability & 0.83 & 0.72 & 4.73 & 0.98 & $0.55^{* *}$ & $0.22 * *$ & $0.55 * *$ & 0.85 & & & \\
\hline 5. Competitive turbulence & 0.87 & 0.63 & 5.23 & 1.06 & $0.57 * *$ & $0.58 * *$ & $0.27 * *$ & $0.40 * *$ & 0.79 & & \\
\hline 6. Competitive advantage & 0.95 & 0.84 & 4.95 & 0.87 & $0.37 * *$ & $0.28 * *$ & $0.30 * *$ & $0.14 *$ & $0.36^{* *}$ & 0.92 & \\
\hline 7. Export Performance & 0.90 & -0.69 & 4.47 & 0.92 & $0.28 * *$ & $0.50 * *$ & 0.11 & $0.30 *$ & $0.38 * *$ & $0.28 * *$ & 0.83 \\
\hline
\end{tabular}

Squared rooted AVEs on diagonal 
Table 2 reports the fit indices for the CFA, as well as the restricted and the unrestricted models tested. The restricted model includes the direct effects of the set of capabilities, namely adaptability, innovativeness, unpredictability, and task flexibility, on competitive advantage and performance, controlling for company size, and number of export staff. The unrestricted model adds the moderating impact of competitive turbulence.

Table 2 Fit Measures

\begin{tabular}{lccccccc}
\hline & $\begin{array}{c}\chi^{2} \\
(\mathrm{df})\end{array}$ & $\begin{array}{c}\chi^{2} \\
/ \mathrm{df}\end{array}$ & $\mathrm{P}$ & GFI & TLI & CFI & RMSEA \\
\hline CFA & $\begin{array}{c}500.397 \\
(254)\end{array}$ & 1.970 & 0.000 & 0.845 & 0.902 & 0.917 & 0.068 \\
Restricted & 39.00 & 3.25 & 0.766 & 0.999 & 1.051 & 1.000 & 0.000 \\
Model & $(12)$ & & & & & & \\
$\begin{array}{l}\text { Unrestricted } \\
\text { Model }\end{array}$ & $\begin{array}{c}17.993 \\
(9)\end{array}$ & 1.999 & 0.035 & 0.989 & 0.866 & 0.989 & 0.069 \\
& & & & & & &
\end{tabular}

CFA - Confirmatory Factor Analysis of all measures

Restricted Model - Structural Model containing the independent, and control variables Unrestricted Model - Structural Model containing independent, moderating, and control variables

GFI - Goodness of Fit Index

TLI - Tucker -Lewis coefficient Index

CFI - Comparative Fit Index

RMSEA - Root Mean Square Error of Approximation 
We analysed the difference between the two models. Based on the model fit changes of $\Delta \chi^{2}=23.685$ and $\Delta \mathrm{df}=4$, we found this difference to be significant at $p<.01$, therefore concluding that the unrestricted model is superior and should be relied upon for hypothesis testing. The results are presented in Table 3.

\section{Table 3 Structural Model Unrestricted Model Results}

\begin{tabular}{|c|c|c|}
\hline Variable name & $\begin{array}{l}\text { Competitive } \\
\text { Advantage } \\
\text { (t-value) }\end{array}$ & $\begin{array}{c}\text { Performance } \\
\text { (t-value) }\end{array}$ \\
\hline \multicolumn{3}{|l|}{ Independent variable } \\
\hline Export adaptability (H1a) & $\begin{array}{l}-0.179 * \\
(-2.329)\end{array}$ & \\
\hline Export innovativeness $(\mathrm{H} 2 \mathrm{a})$ & $\begin{array}{l}0.317 * * \\
(3.926)\end{array}$ & \\
\hline Export unpredictability $(\mathrm{H} 3 \mathrm{a})$ & $\begin{array}{l}0.166^{*} \\
(2.202)\end{array}$ & $\begin{array}{c}0.325^{* *} \\
(4.246)\end{array}$ \\
\hline Export task flexibility (H4a) & $\begin{array}{l}0.159 * \\
(2.462)\end{array}$ & \\
\hline Competitive advantage (H5) & & $\begin{array}{l}0.157 * * \\
(2.610)\end{array}$ \\
\hline \multicolumn{3}{|l|}{ Moderating effects } \\
\hline Export adaptability X Competitive Intensity (H1b) & $\begin{array}{c}0.075 \\
(0.975)\end{array}$ & \\
\hline $\begin{array}{l}\text { Export innovativeness X Competitive Intensity } \\
(\mathrm{H} 2 \mathrm{~b})\end{array}$ & $\begin{array}{l}-0.146 \\
(-1.738)\end{array}$ & \\
\hline $\begin{array}{l}\text { Export unpredictability X Competitive Intensity } \\
(\mathrm{H} 3 \mathrm{~b})\end{array}$ & $\begin{array}{l}-0.284 * * \\
(-3.945)\end{array}$ & \\
\hline Export task flexibility X Competitive Intensity (H4b) & $\begin{array}{c}0.089 \\
(1.184)\end{array}$ & \\
\hline \multicolumn{3}{|l|}{ Control variables } \\
\hline Firm size sales & $\begin{array}{c}0.034 \\
(0.526)\end{array}$ & $\begin{array}{c}0.016 \\
(0.250)\end{array}$ \\
\hline Export staff & $\begin{array}{c}-0.076 \\
(-1.126)\end{array}$ & $\begin{array}{c}0.254 * * \\
(4.044)\end{array}$ \\
\hline Export Experience & $\begin{array}{c}0.085 \\
(1.348)\end{array}$ & $\begin{array}{c}-0.009 \\
(-0.142)\end{array}$ \\
\hline
\end{tabular}

$* \mathrm{p}<0.05 ; * * \mathrm{p}<0.01)$ 
The analysis showed that the moderating impact of competitive intensity on adaptability acted opposite to our expectation. Adaptability has a significant negative relationship with competitive advantage $(\beta=-.173 ; p<.05)$, contradicting H1a. We also found that competitive turbulence is not significant as a moderator $(\beta=.072 ; p>.05)$, therefore $\mathrm{H} 1 \mathrm{~b}$ is not supported. As for task flexibility, the results showed a direct positive relationship between this, and competitive advantage $(\beta=.164 ; p<.05)$, supporting H2a. No moderation effect is found when competitive turbulence is considered. As such then, task flexibility appears to be positively related to advantage regardless of competitive conditions. Therefore, the results suggest lack of support for $\mathrm{H} 2 \mathrm{~b}$.

Innovativeness initially displays a significant positive influence on competitive advantage $(\beta=.327 ; p<.05)$, hence supporting H3a. Under competitive intensity, the moderation effect on this relationship becomes non-significant hence not supporting H3b. Regarding unpredictability, $\mathrm{H} 4 \mathrm{a}$ and $\mathrm{H} 4 \mathrm{~b}$ are supported. Under stable conditions unpredictability shows a positive impact on competitive advantage $(\beta=.162 ; p<.05)$. Yet, as competitive turbulence increases, the relationship between unpredictability, and competitive advantage becomes increasingly negative $(\beta=-.294 ; p<.05)$. For further information on the effects of unpredictability, and based on modification indices, we revealed that out of the four capabilities, unpredictability also shows a significant positive impact directly on performance $(\beta=.342 ; p<.05)$. Finally, competitive advantage returned a significant, and positive impact on performance $((\beta=.154 ; p<.05)$, supporting H5.

\section{Additional Analysis}

Resource-based theory and dynamic capability literature would imply that capabilities have indirect effects on performance. More specifically, their effects on performance come from the creation of competitive advantages for the exporting firm. In this study we hypothesize that the identified dynamic capabilities create competitive advantages, and then competitive advantage enables superior market performance. To examine for indirect mediation effects we conduct additional analysis employing the Sobel test. Following the works of Ndofor, Sirmon, and He (2011) and Hughes, Morgan, Ireland, and Hughes (2014), for full mediation the Sobel Z-statistic must exceed 1.96 for $5 \%$ significance (1.645 for $10 \%$ significance) and the corresponding effect ratio should exceed 0.8; partial mediation will be concluded if the effect ratio is less than 0.8 . 
Results are presented in Table 5. The indirect effect through competitive advantage is statistically significant for all dynamic capabilities. Full mediation is found for task flexibility while a partial mediation effect is found for export adaptability, export innovativeness, and export unpredictability.

Table 4 - Mediation Analysis (Sobel Test)

\begin{tabular}{lccccccc}
\hline & $\mathrm{a}$ & $\mathrm{SE}_{\mathrm{a}}$ & $\mathrm{b}$ & $\mathrm{SE}_{\mathrm{b}}$ & $\mathrm{Z}$ & $\mathrm{c}$ & $\begin{array}{c}\text { Effect } \\
\text { Ratio }\end{array}$ \\
\hline Adaptability $\rightarrow \mathrm{CA} \rightarrow$ Performance & -0.163 & 0.070 & 0.172 & 0.066 & $1.736 \dagger$ & 0.051 & 0.550 \\
Task flexibility $\rightarrow \mathrm{CA} \rightarrow$ Performance & 0.112 & 0.046 & 0.172 & 0.066 & $1.779 \dagger$ & 0.014 & 1.376 \\
Innovativeness $\rightarrow \mathrm{CA} \rightarrow$ Performance & 0.269 & 0.068 & 0.172 & 0.066 & $2.176^{*}$ & -0.058 & 0.798 \\
Unpredictability $\rightarrow \mathrm{CA} \rightarrow$ Performance & 0.147 & 0.067 & 0.172 & 0.066 & $1.678 \dagger$ & 0.319 & 0.079 \\
\hline
\end{tabular}

a Unstandardized path coefficient from independent variable to the mediator variable.

$\mathrm{SE}_{\mathrm{a}}$ Standard error of the relationship between the independent variable and the mediator variable.

b Unstandardized path coefficient from the mediator variable to the dependent variable.

$\mathrm{SE}_{\mathrm{b}}$ Standard error of the relationship between the mediator variable and the dependent variable. Z Sobel test statistic: $Z=a b / \sqrt{ }\left(\left(a^{2} S E_{b}^{2}\right)+\left(b^{2} S E_{a}^{2}\right)\right)$

c Unstandardized path coefficient from independent variable to the dependent variable.

Effect Ratio $=a b / c$

* Significant at 0.05 level (2-tailed).

$\uparrow$ Significant at 0.10 level (2-tailed).

\section{Discussion and Conclusion}

The purpose of present study is to test the extent to which the Dynamic Capabilities Approach (DCA) can explain the sustainable competitive advantage (SCA). We refer to the impact of dynamic capabilities on firm's competitive advantage, a factor long neglected to be tested, in the context of exporting. Based on the literature, four main capabilities were identified (adaptability, innovativeness, unpredictability and task flexibility). Our findings support the core principle that firm's capabilities should be examined in the context of their relevancy to the firm's competitive advantage, following the rationale of structure-conduct-performance.

Before we dive into explaining our findings, we should address the issue of competitive advantage. This will enable a better understanding of the results. Competitive advantage is based on bundles of capabilities facilitating firms' performance. Being as such, it requires careful strategic planning, and adjustments to changing conditions to maintain strategic fit and ensure the most appropriate strategy is followed (Hughes, Hughes, and Morgan, 2010). Furthermore, competitive advantage should be sustained in order to produce the superior value creation on which it is based. Our findings are examined in light of this goal. Linking this to the mediation test's results, we substantiate the basic principle of the DCA, being the role of competitive advantage separately from firm's performance. Competitive advantage, by definition, is the 
combination of resources and capabilities. The fit between these components, and the firm's strengths as well as its environment, dictate the quality of its competitive advantage. Therefore, competitive advantage has a significant role in creating the right balance between the different components while striving for a strategic fit. By confirming the lack of mediation in the impact of the four capabilities on competitive advantage, we reassure our initial positioning, treating competitive advantage as standalone while acknowledging its role in enhancing firm's performance while maintaining strategic fit.

We start by acknowledging the relevance of the capabilities incorporated in the study in explaining firms' SCA. All capabilities show a significant impact on the SCA. However, this changes for some of the capabilities once the competitive intensity embedded within the environment is introduced into the picture as a moderator. We discuss below all the tested relationships in turn.

First, adaptability was found to have a positive relationship with competitive advantage (supporting H1a). Adaptability implies positive connotations for competitive advantage given that as a capability this provides an ability to adapt to shifts in export markets. Chinese export firms clearly benefit from adaptability, regardless the level of competitive intensity (running against $\mathrm{H} 1 \mathrm{~b}$ )

Task flexibility is positively related to competitive advantage (supporting $\mathrm{H} 2 \mathrm{a}$ ), also regardless of competitive conditions. Task flexibility implies non-specialization in terms of workers. This capability is resource-dependent, requiring the investment of substantial amounts of money and time in developing, training and building cross-specialism/task skills in managers, and personnel. In developing multi-skilled staff, firms clearly benefit in having competitive advantages above rivals. This may be due to their ability to more seamlessly distribute staff across the firm to areas that demand strengthening or, for example, to move more staff into marketing, and sales at key sales periods in the year. Regardless of competitive conditions, our results imply that investing in this capability is a must for managers in Chinese exporters.

Innovativeness was found to have a direct positive influence on competitive advantage (supporting $\mathrm{H} 3 \mathrm{a}$ ), whereas the moderation relationship with competitive intensity was found to be insignificant (not supporting H3b). Similarly to adaptability and task flexibility, the focus on innovativeness is strategically important for Chinese firms. For a long time Chinese manufactures were mostly reliant on imitation capability (Zhou, 2006) rather than 
innovativeness. Thought this model seems to be sustainable as the managers realise that they need to come up with new ideas and to identify upcoming trends in export markets to stay competitive (Souchon et al. 2016).

The findings regarding the unpredictability suggest that this capability does have an effect in different competitive conditions (both $\mathrm{H} 4 \mathrm{a}$ and $\mathrm{H} 4 \mathrm{~b}$ are supported). In more stable competitive environment unpredictability is positively related to the SCA, however when the environment becomes more competitive the relationship becomes negative. For unpredictability, what appears beneficial on the surface in having a direct positive impact on advantage becomes very much undesirable when competitive turbulence is accounted for. These findings shed new light on the concept of strategic liabilities advanced by Arend (2004). In extending on Arend's (2004) work, strategic liabilities can be viewed as strategic capabilities that become strategic liabilities as contextual conditions surrounding the firm change. The dynamic capabilities literature puts emphasis on the longitudinal nature of capability development but with the proposed pay off of obtainable competitive advantages. Our findings suggest scholars need to be very careful in advising managers on their strategic priorities regarding unpredictability. Firms could end up in situations where significant amounts of time and resources have been poured into developing a capability base that is ultimately filled with strategic liabilities if they are inconsistent with the contextual conditions that enable them to succeed. Put simply then, those exporters operating in very dynamic and changeable competitive conditions are better served turning to other capabilities for advantage rather than spend resources on unpredictability. Future research should seek to identify capabilities that enable advantage, and superior performance in turbulent environments while also seeking to understand which form the basis for becoming liabilities to firms such that managers can make better decisions on which capabilities to prioritize and develop.

Unpredictability refers to decisions' actioning, and tactics that can surprise rivals that are difficult to forecast, or are unexpected. It has a positive direct impact on delivering competitive advantage which implies that the exporters in question are able to formulate positions of advantage, and superiority in taking such actions, which by their very nature, could be quite different from one to the next. Such an unfocused approach is then desirable, but when coupled with the negative moderation effects from competitive intensity we see situations that show unpredictability to be very much a problematic capability to develop. Perhaps a combination of 
environmental unpredictability from excessive turbulence, and a capacity by the firm to itself be unpredictable is not conducive to success in export markets, or in establishing an identity with customers. We acknowledge that our post hoc tests suggest enhance firm performance from unpredictability but this could be a symptom of the firm becoming involved in multiple different product domains, or arenas, but otherwise spreading itself too thinly to develop advantageous positions from this. Indeed, on average, the exporters in our sample are heavily dependent on exports with $67 \%$ of total sales being accounted for by exports. This would suggest that becoming increasingly unpredictable against rivals in order to further pursue greater export sales is pushing these firms to gain somewhat in performance terms but lose out in the race to develop longer term competitive advantages.

Similar to our expectation, competitive advantage showed a positive impact on firm performance, therefore mediating the impact of capabilities on performance. As such, there is little to recommend but for managers to pursue competitive advantages. However, for management and strategy scholars the means to competitive advantage through dynamic capabilities, and the types of capabilities that create/destroy competitive advantages need further investigation.

Overall, the study confirms path-dependent impacts of capabilities on competitive advantage, and performance. Moreover, the novelty of examining a combination of dynamic capabilities provides a base for further analysis aiming at expanding our understanding of the bundle of capabilities which will serve to strengthen or damage competitive advantage, and whether they are industry-contingent, environment-contingent, or contingent on internal firm factors, therefore addressing the inevitable question "are all capabilities dynamic by nature?" our study clearly shows that under different competitive intensity levels some capabilities ceased to have a positive impact on SCA therefore failed to manifest the core ability expected from dynamic capabilities.

We acknowledge a number of limitations to this study, but also present avenues for future research arising from these. First, because the present study was based on data collected from a wide variety of Chinese firms, differences in strategic orientations may have impacted the findings. Future research should look to examine drivers of export capabilities that are concerned with alternative strategic orientations, such as export market orientation (Cadogan, Diamantopoulos, and De Mortanges, 1999), learning orientation (Souchon, Sy-Changco, and 
Dewsnap, 2012), decision-making orientation (Nemkova, Souchon, and Hughes, 2012), and entrepreneurial orientation (Boso, Story, and Cadogan, 2013). Second, the competitiveness of Chinese companies can also be dependent on access to local resources. Thus the locational advantages can be further investigated as they can vary across different regions in the country. Third, the capabilities tested represent only a partial sample of possible capabilities. Future research should deepen our understanding of the DCA concept by exploring other capabilities, and their relationship with competitive advantage. Fourth, we need to better understand the contingent conditions under which capabilities offer benefits to, or indeed damage, competitive advantage. We do not for instance consider internal firm-level contingencies that could strengthen capabilities, and their relationship to advantage. For example, ownership structure, financial support, and turnover can be further discussed. Finally, the inter-relationships between the different capabilities are themselves of interest. For example, the table of correlations produced from the confirmatory factor analysis reveals that adaptability and task flexibility are strongly positively related to each other. Further research could examine whether similarly categorized capabilities interact with each other to create synergistic, and more positive, or negative, outcomes.

\section{Managerial Implications}

Beyond what has been stressed thus far, we advise managers acting under constant resourceconstrained conditions that the present study provides some insights into the core dynamic capabilities. Therefore it is aiming to help the decision-makers to distribute the company's resources more wisely.

Our results show that the regardless competitive conditions managers have to invest into adaptability, task-flexibility and innovativeness to stay competitive. However, that's not the case for unpredictability. Unpredictability becomes problematic for managers of Chinese exporting firms as they enter or compete in competitively turbulent competitive conditions. What are initially desirable capabilities in forming a basis for competitive advantage soon become strategic liabilities under these conditions (Arend, 2004). This becomes an important issue of balance for managers between desires to manipulate and exploit their existing capability-base with the need to maintain competitive advantage in turbulent times perhaps by moving away from those existing capabilities. These results shed new light on the adherence problem that 
managers face (Covin, Slevin, and Schultz, 1997; Hughes, Hughes, and Morgan, 2010).

Strengths in unpredictability render changes in export, business, or marketing strategy as undesirable if those changes mean deviating away from exploiting this capability. Managers could well choose then to adhere to the existing strategies that do exploit this capability (Covin, Slevin, and Schultz, 1997) but in doing so open up the potential for strategy failure (c.f. Hughes, Hughes, and Morgan, 2010). It follows, then, that monitoring strategy for strategic fit should be a priority for managers in pursuit of competitive advantages and higher performance.

From a marketing perspective, it would appear there are contexts in which adaptability, taskflexibility, export-innovativeness and unpredictability are not desirable capabilities to develop, and exploit. Persistent competitive dynamism may well be leading firms to develop each capability either too late in the game, or in directions that do not suit their export markets, and customers. It could well be then that a market orientation could serve to rebalance this negative effect by focusing innovation efforts on delivering products, services, and innovations that customers value. 


\section{References}

Adner R., \& Zemsky P. (2006). A demand-based perspective on sustainable competitive advantage. Strategic Management Journal, 27/3, 215-239.

Amabile T.M., Conti R., Coon H., Lazenby J., \& Herron M. (1996). Assessing the work environment for creativity. Academy of Management Journal, 39/5, 1154-1184.

Ambrosini V., Bowman C., \& Collier N. (2009). Dynamic capabilities: an exploration of how firms renew their resource base. British Journal of Management, 20/s1, S9-S24.

Arend R.J. (2004). The Definition of Strategic Liabilities, and their Impact on Firm Performance*. Journal of Management Studies, 41/6, 1003-1027.

Armstrong J.S., \& Overton T.S. (1977). Estimating nonresponse bias in mail surveys. Journal of Marketing Research, 14/3, 396-402.

Augier M., \& Teece D.J. (2007). Dynamic capabilities and multinational enterprise: Penrosean insights and omissions. Management International Review, 47/2, 175-192.

Auh S., \& Menguc B. (2005). Balancing exploration and exploitation: The moderating role of competitive intensity. Journal of Business Research, 58/12, 1652-1661.

Austin R.D., Devin L., \& Sullivan E.E. (2012). Accidental innovation: Supporting valuable unpredictability in the creative process. Organization Science, 23/5, 1505-1522.

Barney J., Wright M., \& Ketchen D.J. (2001). The resource-based view of the firm: Ten years after 1991. Journal of Management, 27/6, 625-641.

Bhatt, G., Emdad, A., Roberts, N., \& Grover, V. (2010). Building and leveraging information in dynamic environments: The role of IT infrastructure flexibility as enabler of organizational responsiveness and competitive advantage. Information \& Management, 47/7, 341-349.

Bhaumik S.K., Driffield N., \& Zhou Y. (2016). Country specific advantage, firm specific advantage and multinationality-Sources of competitive advantage in emerging markets: Evidence from the electronics industry in China. International Business Review, 25/1, 165-176.

Boso N., Story V.M., \& Cadogan J.W. (2013). Entrepreneurial orientation, market orientation, network ties, and performance: Study of entrepreneurial firms in a developing economy. Journal of Business Venturing, 28/6, 708-727.

Boso, N., Story, V. M., Cadogan, J. W., Micevski, M., \& Kadic-Maglajlic, S. (2013). Firm innovativeness and export performance: Environmental, networking, and structural contingencies. Journal of Marketing Research, 21/4, 62-87.

Byrd, T. A., \& Turner, D. E. (2001). An exploratory examination of the relationship between flexible IT infrastructure and competitive advantage. Information \& Management, 39/1, 41-52.

Cadogan J.W., Cui C.C., \& Kwok Yeung Li E. (2003). Export market-oriented behavior and export performance: The moderating roles of competitive intensity and technological turbulence. International Marketing Review, 20/5, 493-513.

Cadogan J.W., Diamantopoulos A., \& De Mortanges C.P. (1999). A measure of export market orientation: scale development and cross-cultural validation. Journal of International Business Studies, 689-707.

Cadogan J.W., Diamantopoulos A., \& Siguaw J.A. (2002). Export market-oriented activities: their antecedents and performance consequences. Journal of International Business Studies, 615626. 
Calantone R.J., Garcia R., \& Droge C. (2003). The effects of environmental turbulence on new product development strategy planning. Journal of Product Innovation Management, 20/2, 90103.

Campion M.A., Medsker G.J., \& Higgs A.C. (1993). Relations between work group characteristics and effectiveness: Implications for designing effective work groups. Personnel Psychology, 46, 823-850.

Chadee, D., \& Kumar, R. (2001). Sustaining the international competitive advantage of Asian firms: A conceptual framework and research propositions. Asia Pacific Journal of Management, 18, 461-480.

Cockburn, I.M., Henderson, R.M., \& Stern, S. (2000). Untangling the origins of competitive advantage. Strategic Management Journal, 21/10-11, 1123-1145.

Covin J.G., Slevin D.P., \& Schultz R.L. (1997). Top management decision sharing and adherence to plans. Journal of Business Research, 40/1, 21-36.

Cui A.S., Griffith D.A., \& Cavusgil S.T. (2005). The influence of competitive intensity and market dynamism on knowledge management capabilities of multinational corporation subsidiaries. Journal of International Marketing, 13/3, 32-53.

Damanpour F. (1991). Organizational Innovation: a Meta-Analysis of Effects of Determinants and Moderators. Academy of Management Journal, 34/3, 555-590.

Day G.S. (2011). Closing the Marketing Capabilities Gap. Journal of Marketing, 75/4, 183-195.

Day G.S. (1994). The capabilities of market-driven organizations. Journal of Marketing, 58/4, 37-52.

Deng P. (2009). Why do Chinese firms tend to acquire strategic assets in international expansion? Journal of World Business, 44/1, 74-84.

Dibrell C., Down J., \& Bull L. (2007). Dynamic strategic planning: Achieving strategic flexibility through formalization. Journal of Business and Management, 13/1, 21-36.

Dillman D.A. (2007). Mail and internet surveys. Hoboken.

Doyle P., \& Wong V. (1998). Marketing and competitive performance: an empirical study. European Journal of Marketing, 32/5/6, 514-535.

Eisenhardt K.M., \& Martin J.A. (2000). Dynamic capabilities: what are they? Strategic Management Journal, 21/10-11, 1105-1121.

Fahy J. (2002). A resource-based analysis of sustainable competitive advantage in a global environment. International Business Review, 11/1, 57-77.

Felin, T., Foss, N.J., Heimeriks, K.H., \& Madsen, T.L. (2012). Journal of Management Studies, 49/8, 1351-1374.

Garcia R. (2002). A critical look at technological innovation typology and innovativeness terminology: a literature review. Journal of Product Innovation Management, 19/2, 110-132.

Gibson C.B., \& Birkinshaw J. (2004). The Antecedents, Consequences, and Mediating Role of Organizational Ambidexterity. Academy of Management Journal, 47/2, 209-226.

Grahovac J., \& Miller D.J. (2009). Competitive advantage and performance: the impact of value creation and costliness of imitation. Strategic Management Journal, 30/11, 1192-1212.

Gratton, L., \& Ghoshal, S. (2005). Beyond best practice. MIT Sloan Management Review, 46/3, 49-57. 
Griffith D.A., \& Harvey M.G. (2001). A resource perspective of global dynamic capabilities. Journal of International Business Studies, 32/3, 597-606.

Griffith, D., S. Lee, H., Seob Yeo, C., \& Calantone, R. (2014). Marketing process adaptation: Antecedent factors and new product performance implications in export markets. International Marketing Review, 31/3, 308-334.

Guillen M.F. (2000). Business groups in emerging economies: A resource-based view. Academy of Management Journal, 43/3, 362-380.

Han J.K., Kim N., \& Srivastava R.K. (1998). Market Orientation and Organizational Performance: Is Innovation a Missing Link? Journal of Marketing, 62/4, 30-45.

Harris L.C. (2001). Market orientation and performance: objective and subjective empirical evidence from UK companies. Journal of Management Studies, 38, 17-43.

Helfat C.E., \& Peteraf M.A. (2003). The dynamic resource-based view: Capability lifecycles. Strategic Management Journal, 24/10, 997-1010.

Homburg C., Workman Jr. J.P., \& Krohmer H. (1999). Marketing's Influence Within the Firm. Journal of Marketing, 63/2, 1-17.

Hughes P., Hughes M., \& Morgan R.E. (2010). Why do product-market strategies fail? A sociostructural examination under conditions of adherence. Group \& Organization Management, $35 / 5,606-635$.

Hughes, M., Morgan, R.E., Ireland, R.D., \& Hughes, P. (2014). Social capital and learning advantages: A problem of absorptive capacity. Strategic Entrepreneurship Journal, 8/3, 214-233.

Hult G.T.M., Hurley R.F., \& Knight G.A. (2004). Innovativeness: Its antecedents and impact on business performance. Industrial Marketing Management, 33/5, 429-438.

Hultman M., Robson M.J., \& Katsikeas C.S. (2009). Export product strategy fit and performance: an empirical investigation. Journal of International Marketing, 17/4, 1-23.

Jacobides, M.G., \& Winter, S. G. (2012). Capabilities: Structure, agency, and evolution. Organization Science, 23/5, 1365-1381.

Jacobs R., \& Washington C. (2003). Employee development and organizational performance: a review of literature and directions for future research. Human Resource Development International, 6/3, 343-354.

Jaworski B.J., \& Kohli A.K. (1993). Market orientation: Antecedents and consequences. Journal of Marketing, 57/3, 53-70.

Jayachandran S., Hewett K., \& Kaufman P. (2004). Customer response capability in a sense-andrespond era: The role of customer knowledge process. Journal of the Academy of Marketing Science, 32/3, 219-233.

Kaleka A. (2002). Resources and capabilities driving competitive advantage in export markets: guidelines for industrial exporters. Industrial Marketing Management, 31/3, 273-283.

Kaleka A. (2011). When exporting manufacturers compete on the basis of service: Resources and marketing capabilities driving service advantage and performance. Journal of International Marketing, 19/1, 40-58.

Kaleka A. (2012). Studying resource and capability effects on export venture performance. Journal of World Business, 47/1, 93-105.

Kaleka A., \& Berthon P. (2006). Learning and locale: The role of information, memory and environment in determining export differentiation advantage. Journal of Business Research, 59/9, 1016-1024. 
Leonidou, L. C., Palihawadana, D., \& Theodosiou, M. (2011). National export-promotion programs as drivers of organizational resources and capabilities: effects on strategy, competitive advantage, and performance. Journal of International Marketing, 19/2, 1-29.

Li N., \& Li L.X. (2000). Modeling staffing flexibility: A case of China. European Journal of Operational Research, 124/2, 255-266.

Lin Y., \& Wu L. (2014). Exploring the role of dynamic capabilities in firm performance under the resource-based view framework. Journal of Business Research, 67/3, 407-413.

Lindell M.K., \& Whitney D.J. (2001). Accounting for common method variance in crosssectional research designs. Journal of Applied Psychology, 86/1, 114.

Lisboa A., Skarmeas D., \& Lages C. (2011). Entrepreneurial orientation, exploitative and explorative capabilities, and performance outcomes in export markets: A resource-based approach. Industrial Marketing Management, 40/8, 1274-1284.

López S.V. (2005). Competitive advantage and strategy formulation: the key role of dynamic capabilities. Management Decision, 43/5, 661-669.

Lu Y., Zhou L., Bruton G., \& Li W. (2010). Capabilities as a mediator linking resources and the international performance of entrepreneurial firms in an emerging economy. Journal of International Business Studies, 41/3, 419-436.

Luo Y. (2000). Dynamic capabilities in international expansion. Journal of World Business, 35/4, 355-378.

Lyus D., Rogers B., \& Simms C. (2011). The role of sales and marketing integration in improving strategic responsiveness to market change. Journal of Database Marketing and Customer Strategy Management, 18, 39-49.

Malhotra N.K., Kim S.S., \& Patil A. (2006). Common method variance in IS research: a comparison of alternative approaches and a reanalysis of past research. Management Science, $52 / 12,1865-1883$.

Marukawa, T. (2009). Why Japanese multinationals failed in the Chinese mobile phone market: a comparative study of new product development in Japan and China. Asia Pacific Business Review, 15/3, 411-431.

McNally R.C., Cavusgil E., \& Calantone R.J. (2010). Product innovativeness dimensions and their relationships with product advantage, product financial performance, and project protocol. Journal of Product Innovation Management, 27/7, 991-1006.

Menguc B., \& Auh S. (2006). Creating a Firm-Level Dynamic Capability through Capitalizing on Market Orientation and Innovativeness. Journal of the Academy of Marketing Science, 34/1, 63-73.

Miles R.E., Snow C.C., Meyer A.D., \& Coleman Jr H.J. (1978). Organizational strategy, structure, and process. Academy of Management Review, 3/3, 546-562.

Moorman C., \& Miner A.S. (1998). The convergence of planning and execution: improvisation in new product development. Journal of Marketing, 62/July, 1-20.

Morgan N.A., Kaleka A., \& Katsikeas C.S. (2004). Antecedents of export venture performance: a theoretical model and empirical assessment. Journal of Marketing, 68/1, 90-108.

Morgan, N. A., Zou, S., Vorhies, D. W., \& Katsikeas, C. S. (2003). Experiential and informational knowledge, architectural marketing capabilities, and the adaptive performance of export ventures: A cross-national study. Decision Sciences, 34/2, 287-321.

Morgan N.A., Vorhies D.W., \& Mason C.H. (2009). Market orientation, marketing capabilities, and firm performance. Strategic Management Journal, 30/8, 909-920. 
Murmann J.P. (2013). The coevolution of industries and important features of their environments. Organization Science, 24/1, 58-78.

Murray J.Y., Gao G.Y., \& Kotabe M. (2011). Market orientation and performance of export ventures: The process through marketing capabilities and competitive advantages. Journal of the Academy of Marketing Science, 39/2, 252-269.

Ndofor, H.A., Sirmon, D.G., \& He, X. (2011). Firm resources, competitive actions and performance: investigating a mediated model with evidence from the in-vitro diagnostics industry. Strategic Management Journal, 32/6, 640-657.

Nemkova E., Souchon A.L., \& Hughes P. (2012). Export decision-making orientation: an exploratory study. International Marketing Review, 29/4, 349-378.

Nemkova, E., Souchon, A. L., Hughes, P., \& Micevski, M. (2015). Does improvisation help or hinder planning in determining export success? Decision theory applied to exporting. Journal of International Marketing, 23/3, 41-65.

Newbert S.L. (2008). Value, rareness, competitive advantage, and performance: a conceptuallevel empirical investigation of the resource-based view of the firm. Strategic Management Journal, 29/7, 745-768.

Pavlou, P. A., \& El Sawy, O. A. (2006). From IT leveraging competence to competitive advantage in turbulent environments: The case of new product development. Information Systems Research, 17/3, 198-227.

Peteraf M.A., \& Barney J.B. (2003). Unraveling the resource-based tangle. Managerial and Decision Economics, 24/4, 309-323.

Piercy N.F., Kaleka A., \& Katsikeas C.S. (1999). Sources of competitive advantage in high performing exporting companies. Journal of World Business, 33/4, 378-393.

Podsakoff P.M., MacKenzie S.B., Lee J., \& Podsakoff N.P. (2003). Common Method Biases in Behavioral Research: A Critical Review of the Literature and Recommended Remedies. Journal of Applied Psychology, 88/5, 879.

Powell T.C. (2001). Competitive advantage: logical and philosophical considerations. Strategic Management Journal, 22/9, 875-888.

Prange C., \& Verdier S. (2011). Dynamic capabilities, internationalization processes and performance. Journal of World Business, 46/1, 126-133.

Pudelko M., \& Mendenhall M.E. (2009). The contingent nature of best practices in national competitiveness: The case of American and Japanese innovation processes. European Management Journal, 27/6, 456-466.

Reuter C., Foerstl K., Hartmann E., \& Blome C. (2010). Sustainable global supplier management: the role of dynamic capabilities in achieving competitive advantage. Journal of Supply Chain Management, 46/2, 45-63.

Rose G.M., \& Shoham A. (2002). Export performance and market orientation: Establishing an empirical link. Journal of Business Research, 55/3, 217-225.

Sanchez R. (2004). Understanding competence-based management: Identifying and managing five modes of competence. Journal of Business Research, 57/5, 518-532.

Santos-Vijande M.L., \& Álvarez-González L.I. (2007). Innovativeness and organizational innovation in total quality oriented firms: The moderating role of market turbulence.

Technovation, 27/9, 514-532. 
Sethi R., Smith D.C., \& Park C.W. (2001). Cross-functional product development teams, creativity, and the innovativeness of new consumer products. Journal of Marketing Research, 38/1, 73-85.

Sirmon D.G., Hitt M.A., Arregle J., \& Campbell J.T. (2010). The dynamic interplay of capability strengths and weaknesses: investigating the bases of temporary competitive advantage. Strategic Management Journal, 31/13, 1386-1409.

Souchon A.L., Sy-Changco J.A., \& Dewsnap B. (2012). Learning orientation in export functions: impact on export growth. International Marketing Review, 29/2, 175-202.

Sousa C.M.P., Martínez-López F.J., \& Coelho F. (2008). The Determinants of Export Performance: A Review of the Research in the Literature between 1998 and 2005. International Journal of Management Reviews, 10/4, 343-374.

Sousa C. M.P, Ruzo E., \& Losada F. (2010). The key role of managers' values in exporting: Influence on customer responsiveness and export performance. Journal of International Marketing, 18/2, 1-19.

Spector P.E., \& Brannick M.T. (1995). The nature and effects of method variance in organizational research. International Review of Industrial and Organizational Psychology West Sussex: John Wiley, 249.

Sun M., \& Tse E. (2009). The Resource-Based View of Competitive Advantage in Two-Sided Markets. Journal of Management Studies, 46/1, 45-64.

Teece, D.J. (2007). Explicating dynamic capabilities: The nature and microfoundations of (sustainable) enterprise performance. Strategic Management Journal, 28/13, 1319-1350.

Teece, D.J. (2012). Dynamic capabilities: Routines versus entrepreneurial action. Journal of Management Studies, 49/8, 1395-1401.

Teece, D.J. (2013). Dynamic capabilities and strategic management: organizing for innovation and growth. Oxford: Oxford University Press.

Teece, D.J. (2014). The foundations of enterprise performance: dynamic and ordinary capabilities in an (economic) theory of firms. Academy of Management Perspectives, 28/4, 328352.

Teece, D.J., Pisano, G., \& Shuen, A. (1997). Dynamic capabilities and strategic management. Strategic Management Journal, 18/7, 537-533.

Tseng C., \& Lee R.P. (2010). Host environmental uncertainty and equity-based entry mode dilemma: The role of market linking capability. International Business Review, 19/4, 407-418.

Van den Bosch, Frans A.J., Volberda H.W., \& de Boer M. (1999). Coevolution of firm absorptive capacity and knowledge environment: organizational forms and combinative capabilities. Organization Science, 10/5, 551-568.

Van Der Vegt, Geben S., Bunderson S., \& Kuipers B. (2010). Why turnover matters in selfmanaging work teams: learning, social integration, and task flexibility. Journal of Management, 36/5, 1168-1191.

Verbeke A., \& Yuan W. (2013). The Drivers of multinational enterprise subsidiary entrepreneurship in china: a new resource-based view perspective. Journal of Management Studies, 50/2, 236-258.

Verdú-Jover A.J., Gomez-Gras J., \& Lloréns-Montes F.J. (2008). Exploring managerial flexibility: determinants and performance implications. Industrial Management \& Data Systems, 108/1, 70-86. 
Villar C., Alegre J., \& Pla-Barber J. (2014). Exploring the role of knowledge management practices on exports: A dynamic capabilities view. International Business Review, 23/1, 38-44.

Volberda H.W. (1996). Toward the flexible form: How to remain vital in hypercompetitive environments. Organization Science, 7/4, 359-374.

Wang C.L., \& Ahmed P.K. (2004). The development and validation of the organizational innovativeness construct using confirmatory factor analysis. European Journal of Innovation Management, 7/4, 303-313.

Weerawardena J., \& Mavondo F.T. (2011). Capabilities, innovation and competitive advantage. Industrial Marketing Management, 40/8, 1220-1223.

Wei Y.S., Samiee S., \& Lee R.P. (2014). The influence of organic organizational cultures, market responsiveness, and product strategy on firm performance in an emerging market. Journal of the Academy of Marketing Science, 42/1, 49-70.

Winter S.G. (2003). Understanding dynamic capabilities. Strategic Management Journal, 24/10, 991-995.

Wu A., \& Voss H. (2015). When does absorptive capacity matter for international performance of firms? Evidence from China. International Business Review, 24/2, 344-351.

Yalcinkaya G., Calantone R.J., \& Griffith D.A. (2007). An examination of exploration and exploitation capabilities: Implications for product innovation and market performance. Journal of International Marketing, 15/4, 63-93.

Yalcinkaya G., \& Griffith D.A. (2007). An Examination of Exploration and Exploitation Capabilities: Implications for Product Innovation and Market Performance. Journal of International Marketing, 15/4, 63-93. 
Figure 1 - Research Model

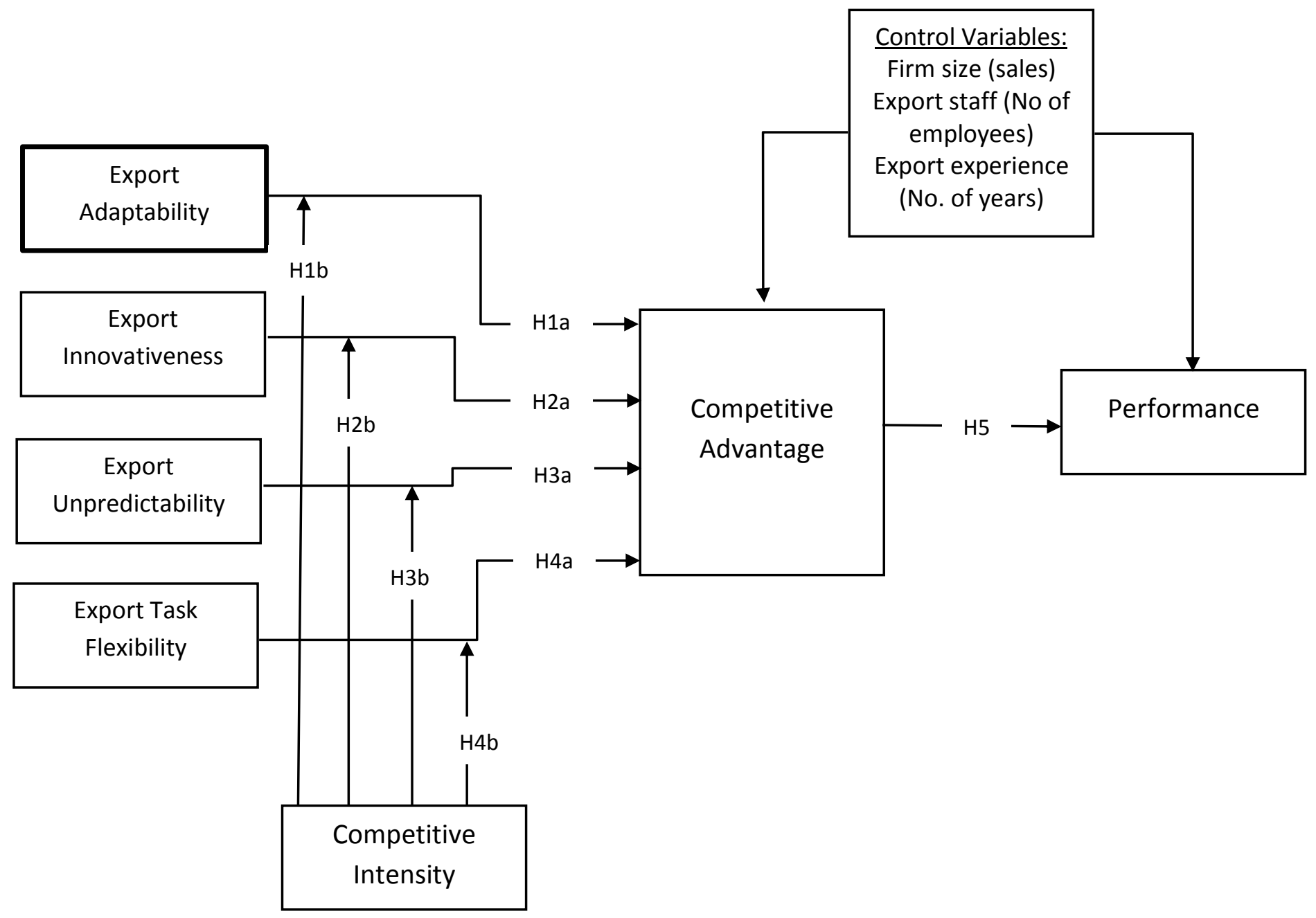




\begin{tabular}{|c|c|c|}
\hline Construct & Measurement Item & $\begin{array}{c}\text { Standardized } \\
\text { Factor } \\
\text { Loading }\end{array}$ \\
\hline $\begin{array}{l}\text { Export } \\
\text { adaptability }\end{array}$ & $\begin{array}{l}\text { If a major competitor were to launch an intensive } \\
\text { campaign targeted at our foreign customers, we would } \\
\text { adapt immediately } \\
\text { We are very quick to adapt to significant changes in } \\
\text { our competitors price structures in foreign markets } \\
\text { We can easily adapt to competitive actions which } \\
\text { threaten us in our export markets }\end{array}$ & .85 \\
\hline $\begin{array}{l}\text { Export } \\
\text { innovativeness }\end{array}$ & $\begin{array}{l}\text { We are very able at using new methods and ideas in } \\
\text { our export production process } \\
\text { We are very good at identifying trends and } \\
\text { competitors' movements in export markets } \\
\text { We are very good at adopting innovative export } \\
\text { marketing techniques }\end{array}$ & .81 \\
\hline $\begin{array}{l}\text { Export } \\
\text { unpredictabilit }\end{array}$ & $\begin{array}{l}\text { Most of our export competitors find it very hard to } \\
\text { predict what we are going to do next } \\
\text { We have been known to surprise our export } \\
\text { competition with the unusualness of our products } \\
\text { One of our strengths is that we produce unexpected } \\
\text { export ideas } \\
\text { Our export competitive actions are unforeseeable }\end{array}$ & $\begin{array}{l}.84 \\
.87 \\
.85\end{array}$ \\
\hline $\begin{array}{l}\text { Export task } \\
\text { flexibility }\end{array}$ & $\begin{array}{l}\text { Export employees always work across different } \\
\text { functions within the firm } \\
\text { All our export employees in this firm multitask, doing } \\
\text { jobs in other departments e.g. service and support, } \\
\text { marketing, sales, finance etc.) } \\
\text { All our export staff have multifunctional } \\
\text { responsibilities across different departments }\end{array}$ & .82 \\
\hline $\begin{array}{c}\text { Competitive } \\
\text { turbulence }\end{array}$ & $\begin{array}{l}\text { Competition in the majority of our export-market is } \\
\text { cut-throat } \\
\text { Price competition is hallmark in our export-markets } \\
\text { We often hear of new export competitive moves } \\
\text { This export-market is competitive; price wars often } \\
\text { occur }\end{array}$ & $\begin{array}{l}.77 \\
.77 \\
.79 \\
.79\end{array}$ \\
\hline $\begin{array}{l}\text { Competitive } \\
\text { advantage }\end{array}$ & $\begin{array}{l}\text { Cost of sales } \\
\text { Product differentiation } \\
\text { New product introduction } \\
\text { Product line breadth/depth }\end{array}$ & $\begin{array}{l}.64 \\
.80 \\
.75 \\
.60\end{array}$ \\
\hline $\begin{array}{l}\text { Export } \\
\text { Performance }\end{array}$ & $\begin{array}{l}\text { Export customer satisfaction } \\
\text { Retention of export customers } \\
\text { New referrals from existing export customers } \\
\text { Acquiring new export customers }\end{array}$ & $\begin{array}{l}.77 \\
.82 \\
.74 \\
.76\end{array}$ \\
\hline
\end{tabular}

